\title{
Inflammatory Genes Are Upregulated in Expanded Ataxin-3- Expressing Cell Lines and Spinocerebellar Ataxia Type 3 Brains
}

\author{
Bernd O. Evert, ${ }^{1}$ Ina R. Vogt,, ${ }^{1}$ Claudia Kindermann, ${ }^{1}$ Lucia Ozimek, ${ }^{1}$ Rob A. I. de Vos, ${ }^{2}$ Ewout R. P. Brunt, ${ }^{3}$ \\ Ina Schmitt, ${ }^{1}$ Thomas Klockgether, ${ }^{1}$ and Ullrich Wüllner ${ }^{1}$ \\ ${ }^{1}$ Department of Neurology, University of Bonn, 53105 Bonn, Germany, 2Laboratorium Pathologie Oost Nederland, 7512 \\ AD Enschede, The Netherlands, and ${ }^{3}$ Department of Neurology, University of Groningen, 9713 AW Groningen, The \\ Netherlands
}

Spinocerebellar ataxia type 3 (SCA3) is a polyglutamine disorder caused by a CAG repeat expansion in the coding region of a gene encoding ataxin-3. To study putative alterations of gene expression induced by expanded ataxin-3, we performed PCRbased cDNA subtractive hybridization in a cell culture model of SCA3. In rat mesencephalic CSM14.1 cells stably expressing expanded ataxin-3, we found a significant upregulation of mRNAs encoding the endopeptidase matrix metalloproteinase 2 (MMP-2), the transmembrane protein amyloid precursor protein, the interleukin-1 receptor-related Fos-inducible transcript, and the cytokine stromal cell-derived factor $1 \alpha$ (SDF1 $\alpha)$. Immunohistochemical studies of the corresponding or associated proteins in human SCA3 brain tissue confirmed these findings, showing increased expression of MMP-2 and amyloid $\beta$-protein

Spinocerebellar ataxia type 3 (SCA3) or Machado-Joseph disease, is the most common dominantly inherited ataxia. Clinically, it is characterized by progressive ataxia in combination with various noncerebellar symptoms, including oculomotor abnormalities, spasticity, basal ganglia symptoms, peripheral neuropathy, and cognitive disturbances (Bürk et al., 1996; Dürr et al., 1996). SCA3, like Huntington's disease (HD), dentatorubralpallidoluysian atrophy, spinobulbar muscular atrophy, and the spinocerebellar ataxia types 1, 2, 6, and 7 (SCA1, SCA2, SCA6, and SCA7, respectively), is caused by a CAG trinucleotide repeat expansion (for review, see Robitaille et al., 1997; Cummings and Zoghbi, 2000; Evert et al., 2000; Paulson, 2000). The SCA3 gene encodes ataxin-3, a cytoplasmic protein of yet unknown function. Although ataxin-3 is ubiquitously expressed, neuronal death occurs preferentially in distinct subcortical brain regions, including the pontine nuclei, the dentate nucleus, the subthalamic nucleus, and the spinal cord (Takiyama et al., 1994; Schmidt et al., 1998). As in other polyglutamine disorders, neuronal intranuclear inclusions (NIs) formed by aggregation of the expanded disease protein are found in affected brain regions. In SCA3, NIs are particularly frequent in the ventral pons (Paulson et al., 1997a,b; Schmidt et al., 1998; Trottier et al., 1998). NIs are ubiquitinated, and two model systems of SCA3 have shown that NIs contain

Received Nov. 7, 2000; revised April 3, 2001; accepted April 10, 2001.

This work was supported by the Bundesministerium für Bildung und Forschung, a University of Bonn Forschuugsförderuug grant, and the National Ataxia Foundation. We thank M. T. Heneka for helpful discussions and for critical reading of this manuscript.

Dr. Bernd O. Evert, Department of Neurology, University of Bonn, SigmundFreud-Strasse 25, 53105 Bonn, Germany. E-mail: b.evert@uni-bonn.de.

Copyright (C) 2001 Society for Neuroscience 0270-6474/01/215389-08\$15.00/0
$(A \beta)$ in pontine neurons containing nuclear inclusions. In addition, extracellular $\mathrm{A} \beta$-immunoreactive deposits were detected in human SCA3 pons. Furthermore, pontine neurons of SCA3 brains strongly expressed the antiinflammatory interleukin-1 receptor antagonist, the proinflammatory cytokine interleukin$1 \beta$, and the proinflammatory chemokine SDF1. Finally, increased numbers of reactive astrocytes and activated microglial cells were found in SCA3 pons. These results suggest that inflammatory processes are involved in the pathogenesis of SCA3.

Key words: spinocerebellar ataxia 3; polyglutamine disease; neurodegeneration; cell death; inflammation; gene expression; ataxin-3 components of the $26 \mathrm{~S}$ proteasome complex, as well as certain heat shock proteins (Chai et al., 1999a,b; Warrick et al., 1999).

Studies in a cell model of HD and SCA1 mice have shown that presence of the expanded disease proteins within the nucleus is required for neurodegeneration (Klement et al., 1998; Saudou et al., 1998). Within the nucleus, expanded ataxin-1, -3 , and -7 are preferentially found in specific subnuclear structures, i.e., the promyelocytic leukemia antigen oncogenic domains that are known to be important for transcriptional regulation (Skinner et al., 1997; Chai et al., 1999a; Kaytor et al., 1999). In cells transiently transfected with expanded ataxin-3 and in human SCA3 disease tissue, the transcription factors CBP [cAMP response element-binding protein (CREB)-binding protein] and TBP (TATA-binding protein) are recruited into NIs, pointing to a direct interaction of the expanded disease proteins with specific transcription factors (Perez et al., 1998; McCampbell et al., 2000). Furthermore, recent studies showed that normal as well as expanded full-length ataxin-3 associate with the nuclear matrix and adopt a novel conformation, probably enabling interactions with nuclear proteins (Tait et al., 1998; Perez et al., 1999). Together, these studies strongly suggest that the expanded disease proteins in CAG repeat disorders cause transcriptional dysregulation. Indeed, gene transcription has been shown to be altered in transgenic SCA1 mice and a cell model of HD (Lin et al., 2000; Luthi-Carter et al., 2000).

Recently, we reported that rat mesencephalic CSM14.1 cells expressing a high level of human expanded full-length ataxin-3 develop NIs and undergo spontaneous non-apoptotic cell death (Evert et al., 1999). In this study, we show a significant upregulation of mRNAs encoding matrix metalloproteinase 2 (MMP-2), 
amyloid precursor protein (APP), the interleukin-1 receptorrelated Fos-inducible transcript (Fit-1S), and the cytokine stromal cell-derived factor $1 \alpha(\mathrm{SDF} 1 \alpha)$ in cells expressing expanded ataxin-3. We further demonstrate that expression of the corresponding (MMP-2 and SDF1) or associated proteins [amyloid $\beta$-protein $(\mathrm{A} \beta)$, interleukin-1 receptor antagonist (IL-1ra), and interleukin-1 $\beta$ (IL-1 $\beta)$ ] is significantly increased in human SCA3 pons.

\section{MATERIALS AND METHODS}

Cell lines and time course analysis. Identification of upregulated genes was performed using the previously generated inducible rat mesencephalic CSM14.1 clonal cell lines expressing nonexpanded (SCA3-Q23) or expanded (SCA3-Q70) human full-length ataxin-3 (Evert et al., 1999). In these cell lines, expression of the human full-length ataxin-3 isoforms is induced after withdrawal of tetracycline. Shifting cells from the permissive temperature $\left(33^{\circ} \mathrm{C}\right)$ to the nonpermissive temperature $\left(39^{\circ} \mathrm{C}\right)$ results in differentiation to postmitotic neuronal cells after $7 \mathrm{~d}$ of culture. The conditions for cell culture, neuronal differentiation, and induction of recombinant ataxin-3 expression used in this study were identical to those described previously.

For time course analysis, cells were seeded in 100-mm-diameter tissue culture plates in Dulbecco's modified Eagle's medium (Life Technologies, Eggenstein, Germany) containing $10 \%$ heat-inactivated fetal calf serum, $100 \mathrm{U} / \mathrm{ml}$ penicillin, $100 \mu \mathrm{g} / \mathrm{ml}$ streptomycin, and $1 \mu \mathrm{g} / \mathrm{ml}$ tetracycline. The number of cells used at the permissive temperature $\left(33^{\circ} \mathrm{C}\right)$ were $10.0,2.0,0.5$, and $0.1 \times 10^{6}$ for $1,7,14$, and $21 \mathrm{~d}$ of induced and uninduced recombinant ataxin-3 expression, respectively. At the nonpermissive temperature $\left(39^{\circ} \mathrm{C}\right) 10.0,4.0,2.0$, and $1.0 \times 10^{6}$ cells were used for $1,7,14$, and $21 \mathrm{~d}$ of induced and uninduced recombinant ataxin- 3 expression, respectively. All plates were preincubated overnight at $33^{\circ} \mathrm{C}$, and then the respective plates were switched to $39^{\circ} \mathrm{C}$ for neuronal differentiation. At the same time, expression of recombinant ataxin-3 was induced by replacing the tetracycline-containing medium through fresh medium without tetracycline, whereas cells plated for the analysis of the uninduced condition received fresh tetracycline-containing medium.

PCR-based cDNA subtractive hybridization and differential screening. Subtractive hybridization was performed using mRNA derived from two individual CSM14.1 clonal cell lines, SCA3-Q70 (Q70\#1) and SCA3Q23 (Q23\#2), expressing expanded and nonexpanded human full-length ataxin-3, respectively, for $7 \mathrm{~d}$ at $33^{\circ} \mathrm{C}$. The subtraction was performed in one direction with $S C A 3-Q 70$ mRNA as the tester and $S C A 3-Q 23$ mRNA as the driver, resulting in identification of upregulated genes. Briefly, 200 $\mu \mathrm{g}$ of total RNA from each cell line was used to isolate polyadenylated RNA using Oligotex kit (Qiagen, Hilden, Germany) and further processed using PCR-Select cDNA subtraction kit (Clontech, Palo Alto, CA) following precisely the instructions of the manufacturer. The subtracted cDNA library was subsequently generated by direct subcloning using AdvanTAge PCR cloning kit (Clontech). Differential screening of the cDNA library was performed using forward and reverse subtracted probes generated with Q70\#1 and Q23\#2 mRNA serving as either tester or driver according to the instructions supplied in the Differential Screening kit (Clontech). Four hundred clones from the subtracted cDNA library were screened, and 33 clones were identified by an at least fivefold increased signal intensity compared with respective clones on the reference filter. These cDNA clones were subjected to sequence analysis on an ABI 373 sequencer (Applied Biosystems, Foster City, CA) and identified by comparing the derived sequences with the database of the National Center for Biotechnology Information.

RNA preparation, Northern, and Western blot analysis. Total RNA was isolated from two individual clonal cell lines (1 and 2) stably expressing nonexpanded (Q23) or expanded (Q70) ataxin-3 after the indicated time points of induced and uninduced expression at the permissive $\left(33^{\circ} \mathrm{C}\right)$ and nonpermissive temperature $\left(39^{\circ} \mathrm{C}\right)$. The differentially expressed genes were also analyzed in RNA from the double-stable mock-transfected CSM14.1 control cell line prepared under identical conditions to evaluate possible side effects resulting from overexpression of the recombinant ataxin-3 isoforms. For isolation, cells were homogenized and disrupted using QiaShredder (Qiagen) and RNA was isolated using RNeasy columns (Qiagen) according to the instructions of the manufacturer.

For Northern blot analysis, $10 \mu \mathrm{g}$ of each RNA sample were denatured in $1 \times 3-(N$-morpholino)propanesulfonic acid containing $30 \%$ formamide and $5 \%$ formaldehyde, electrophoresed through a $1.0 \%$ agarose gel containing $1.2 \%$ formaldehyde, and transferred to Hybond nylon mem- brane (Amersham Pharmacia Biotech, Braunschweig, Germany) by vacuum blotting. The relative amounts of RNA on the blots were evaluated by methylene blue staining of the nylon membranes before hybridization. The specific probes for Northern hybridization of the differentially expressed genes $M M P-2, A P P, S D F 1 \alpha$, and Fit-1S were generated by PCR amplification of the corresponding isolated cDNA clones from subtraction using universal M13 primers. The SCA3 probe was prepared by PCR amplification of the previously described response plasmid pUHDSCA3-Q23 (Evert et al., 1999), using as forward primer 5'GCAGCCTTCTGGAAATATGG-3' and reverse primer 5'-AGCT GAATAGCCCTGCGGAG-3' generating an N-terminal SCA3 cDNA fragment of $575 \mathrm{bp}$. PCR products were then purified using PCR purification spin columns (Qiagen), ${ }^{32} \mathrm{P}$-radiolabeled with RadPrime labeling kit (Life Technologies) and hybridized in ExpressHyb hybridization solution (Clontech) according to the instructions of the manufacturer. Hybridization was detected by autoradiography and intensifying screens after $-80^{\circ} \mathrm{C}$ incubation of $\sim 20 \mathrm{hr}$.

For Western blot analysis, protein lysates were prepared from cells, and $50 \mu \mathrm{g}$ of each protein sample were analyzed after electrophoresis and blotting using the monoclonal antibody $1 \mathrm{H} 9$ as described previously (Evert et al., 1999).

Gelatin zymography. For zymography analysis, the serum-containing medium was aspirated and replaced with serum-free medium. The cells were then further incubated for $24 \mathrm{hr}$ at the respective temperatures, and the conditioned medium was collected at the indicated time points and clarified by a brief centrifugation. Conditioned media from cells incubated at 33 and $39^{\circ} \mathrm{C}$ were concentrated $\sim 10$ times using Ultrafree- 15 centrifugal filter devices (Millipore, Bedford, MA), and protein concentration was determined using the Bradford assay (Bio-Rad, München, Germany). For electrophoresis, $50 \mu \mathrm{g}$ of protein aliquots were mixed with an equal volume of $2 \times$ Laemmli's sample buffer without reducing agents and without heating and separated for $3 \mathrm{hr}$ in $10 \%$ polyacrylamide gels with gelatin (Ready Gel; Bio-Rad). Gels were washed twice for 30 min with wash buffer (50 mm Tris and $2.5 \%$ Triton X-100, pH 7.5). The in-gel gelatinolytic reactions were performed by incubating the gels in incubating buffer $(50 \mathrm{~mm}$ Tris, $10 \mathrm{mM} \mathrm{CaCl}, 0.05 \% \mathrm{NaN} 3$, and $0.02 \%$ Brij-35, pH 7.5) at $37^{\circ} \mathrm{C}$ overnight. Gels were stained for $30 \mathrm{~min}$ in $0.2 \%$ Coomassie blue R, $90 \%$ methanol, and $10 \%$ acetic acid to achieve optimum contrast. Gelatin-degrading activity appeared as a clear zone in a dark blue background after Coomassie blue staining.

Immunohistochemistry and immunofluorescence. For immunohistochemistry of brain sections, $6 \mu \mathrm{m}$ sections of paraffin-embedded tissue were processed and stained using the peroxidase-DAB technique as described previously (Wüllner et al., 1999). Sections were typically counterstained with hematoxylin. The antibodies and dilutions used in this study were as follows: rabbit polyclonal anti-human MMP-2 antibody (1:800; Chemicon, Temecula, CA); mouse monoclonal anti-human A $\beta$ (amino acid residues 1-16) antibody (1:100; Chemicon); goat polyclonal anti-human IL-1ra antibody (1:20; R \& D Systems, Minneapolis, MN); goat polyclonal anti-human IL-1 $\beta$ antibody (1:20; R \& D Systems); goat polyclonal anti-human SDF1 antibody (1:100; R \& D Systems); mouse monoclonal anti-human CD68 antibody (1:25; Dako, Hamburg, Germany); and rabbit polyclonal anti-human glial fibrillary acidic protein (GFAP) (1:800; Dako). Antibody concentrations were first optimized by screening several dilutions against appropriate control brain sections to verify that the specific antigen was detected. For this purpose, Alzheimer's disease neocortical sections were used for A $\beta$, IL-1ra, IL- $1 \beta$, and SDF1 immunostaining, and glioblastoma sections for MMP-2 and SCA3 pons sections for ubiquitin. The SCA3 brain tissues were derived from two patients with genetically confirmed diagnosis of SCA3 (one female of 59 years and one male of 62 years), and three unaffected individuals (three males of 44, 51, and 64 years) without a history of neurological illness served as control and are referred to as "healthy." The number of $\mathrm{A} \beta$-positive deposits and $\mathrm{A} \beta$-positive neurons was determined on two pontine sections per case per antibody at the level of the caudal locus ceruleus by a blinded observer (L.O.).

For coimmunofluorescence studies of brain tissue, SCA3 pons sections were labeled with mouse monoclonal anti-ubiquitin antibody (1:25; Novocastra, Newcastle, UK) together with anti-MMP-2 (1:800) and rabbit polyclonal anti-ubiquitin antibody (1:200; Dako) together with antihuman $\mathrm{A} \beta$ (1:80), followed by fluorescein [5-([4,6-dichlorotriazin-2yl]amino) fluorescein] goat anti-rabbit and Texas Red goat anti-mouse (Jackson ImmunoResearch, West Grove, PA). Samples were observed with a Nikon (Tokyo, Japan) Eclipse E800 fluorescence microscope, and digitized images were collected on separate fluorescence channels using a 
Sony (Tokyo, Japan) 3CCD digital camera and assembled with Adobe Photoshop (Adobe Systems, San Jose, CA).

\section{RESULTS}

\section{Identification of upregulated genes in expanded ataxin-3-expressing cell lines}

The SCA3 model used in this study includes several rat mesencephalic CSM14.1 clonal cell lines that stably express human full-length ataxin-3 with a nonexpanded repeat (SCA3-Q23) or an expanded repeat (SCA3-Q70) under the transcriptional control of a tetracycline-responsive promoter (Evert et al., 1999). These cell lines provide high-level expression of the recombinant ataxin-3 isoforms after withdrawal of tetracycline. Shifting cells from the permissive temperature $\left(33^{\circ} \mathrm{C}\right)$ to the nonpermissive temperature $\left(39^{\circ} \mathrm{C}\right)$ results in differentiation to a neuron-like state within $7 \mathrm{~d}$. In neuronally differentiating cells expressing expanded ataxin-3 at $39^{\circ} \mathrm{C}$, NIs are readily detectable at $3 \mathrm{~d}$ by electron microscopy, although significant neuronal cell death does not occur before day 20. To identify genes upregulated before cell death, we performed PCR-based cDNA subtraction using mRNA isolated from two individual clonal cell lines expressing nonexpanded (SCA3-Q23) or expanded (SCA3-Q70) ataxin-3 for $7 \mathrm{~d}$. Five clones from the subtracted cDNA library representing four different genes displayed a significant increase in SCA3-Q70 clonal cell lines: $M M P-2, A P P$, Fit-1S, and $S D F 1 \alpha$. (Fig. $1 A$ ).

\section{Upregulation of MMP-2 and increased expression of MMP-2 in SCA3 pons}

Clone 1 represented 232 bp of the coding region of the rat gelatinase A (Harendza et al., 1995) also denoted as MMP-2. MMP-2 belongs to the family of matrix metalloproteinases that are involved in remodeling and degradation of the extracellular matrix (Woessner, 1991). A single MMP-2 transcript of $\sim 3.0 \mathrm{~kb}$ was upregulated at 33 and $39^{\circ} \mathrm{C}$ in both SCA3-Q70 clonal cell lines after $7 \mathrm{~d}$ of induced ataxin-3 expression (Fig. $1 \mathrm{~A}$ ). At $39^{\circ} \mathrm{C}$, the significant upregulation of $M M P-2$ mRNA in SCA3-Q70 clonal cell line 1 corresponded to an increased amount of expanded $S C A 3$ mRNA and ataxin-3 protein (Fig. $1 B$ ). $M M P-2$ mRNA was almost absent in SCA3-Q23 clonal cell lines at $33^{\circ} \mathrm{C}$, whereas the SCA3-Q23 clonal cell lines and the control cell line at $39^{\circ} \mathrm{C}$ exhibited a weaker but distinct $M M P-2$ mRNA expression (Fig. $1 A$ ). The differences of the $M M P-2$ transcription observed in SCA3-Q23 clonal cell lines 1 and 2 at $39^{\circ} \mathrm{C}$ were not reflected by different amounts of the nonexpanded $S C A 3$ mRNA or ataxin-3 protein (Fig. $1 B$ ).

To study the time course analysis of $M M P-2$ upregulation, the level of generated $M M P-2$ mRNA was determined by Northern blot analysis and compared with the level of secreted proteolytically active MMP-2 forms by gelatin zymography after 1, 7, 14, and $21 \mathrm{~d}$ of cell culture. At $33^{\circ} \mathrm{C}$, Northern analysis revealed that $M M P-2$ transcription in the induced SCA3-Q70 cell line increased significantly until day 7 and then decreased continuously until day 21, whereas uninduced SCA3-Q70 cells showed a strong but less intense $M M P$-2 signal (Fig. $2 A$ ). Zymographic analysis confirmed an increase of gelatinolytic activity of both pro $(68 \mathrm{kDa})$ and active forms, including the intermediate $(64 \mathrm{kDa})$ and mature $(62$ $\mathrm{kDa}$ ) form of MMP-2 until day 14 in SCA3 Q70 cells (Fig. 2A). In contrast, we observed only small amounts of MMP-2 mRNA and a slight increase of the pro and intermediate form of MMP-2 in induced or uninduced SCA3-Q23 cells at the respective time points (Fig. $2 A$ ). At $39^{\circ} \mathrm{C}, M M P-2$ transcription in the induced SCA3-Q70 cell line increased strongly until day 14 and decreased
A

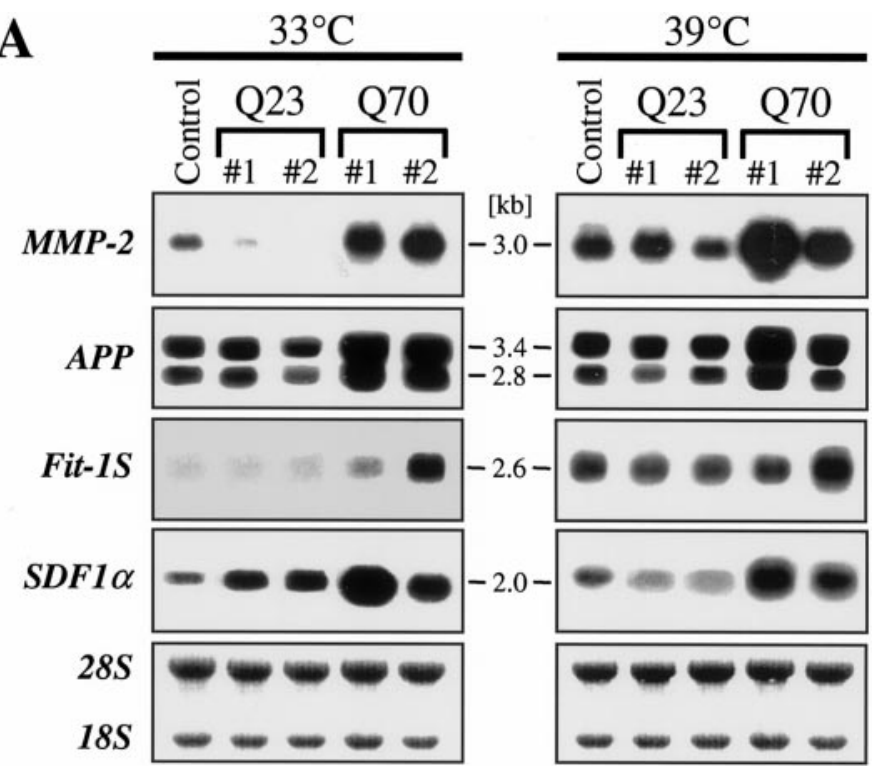

B
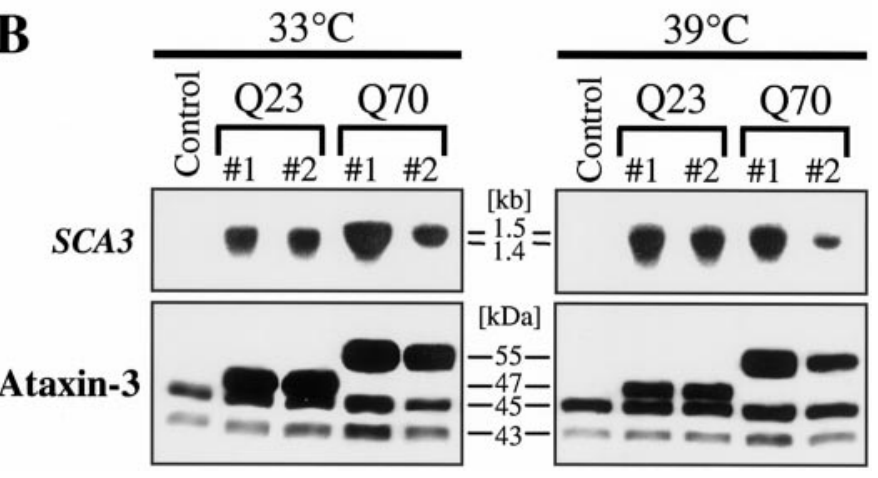

Figure 1. Upregulated genes in CSM14.1 cell lines expressing expanded ataxin-3. For each identified gene, the altered expression was analyzed by Northern blot analyses of total RNA isolated from two individual clonal cell lines (clones 1 and 2) of each stable transfection (SCA3-Q23 and SCA3-Q70) and the mock-transfected control cell line (control) after $7 \mathrm{~d}$ of induced expression. Furthermore, differential expression of the identified genes was analyzed in both proliferating and neuronally differentiated cells at 33 and $39^{\circ} \mathrm{C}$, respectively. $A$, Substantially altered mRNA levels were found for transcripts encoding $M M P-2, A P P$, Fit-1S, and $S D F 1 \alpha$ in both Q70 clonal lines. Northern blot analysis was performed using $10 \mu \mathrm{g}$ of RNA and the indicated cDNAs as probes. Equal loading of RNA in each lane is shown by methylene blue staining of $28 \mathrm{~S}$ and $18 \mathrm{~S}$ rRNA species (two representative images are shown). $B$, Northern (top panels) and Western blot analysis (bottom panels) showing the corresponding transgene levels of the respective $S C A 3$ mRNAs and ataxin-3 protein isoforms in the different clonal SCA3 cell lines, respectively. The nonexpanded and expanded human full-length $S C A 3$ mRNAs were detected as $\sim 1.4$ and $1.5 \mathrm{~kb}$ transcripts, respectively, and were not present in the mock-transfected control cell line. The corresponding recombinant ataxin-3 isoforms were detected as 55 and $47 \mathrm{kDa}$ immunoreactive bands for expanded and nonexpanded human full-length ataxin-3, respectively. The endogenous rat ataxin-3 appeared as 45 and $43 \mathrm{kDa}$ immunoreactive bands.

at day 21 (Fig. 2B). Consistently, we observed an increased expression of gelatinolytic active pro $(68 \mathrm{kDa})$, intermediate $(64$ $\mathrm{kDa})$, and mature (62 kDa) forms of MMP-2 until day 14 and a slight decrease at day 21 with induced SCA3 Q70 cells (Fig. 2B). In contrast, $M M P$ - 2 transcription was significantly lower and remained nearly constant over time in induced and uninduced SCA3-Q23 cells compared with SCA3-Q70 cells. Although a slight increase in gelatinolytic activities of the pro and interme- 
A
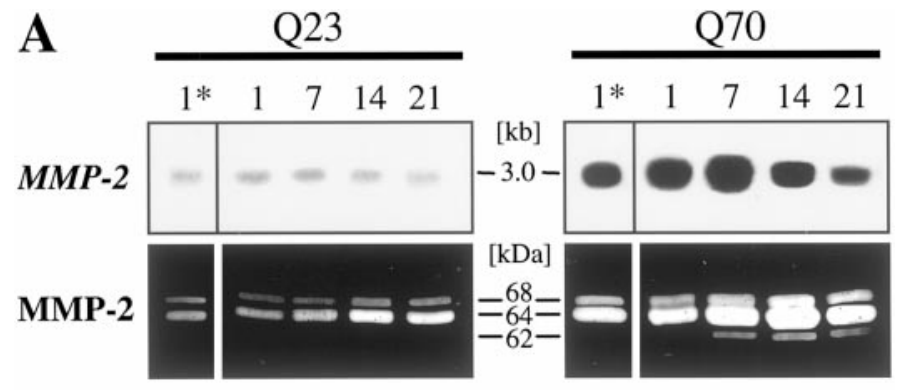

B
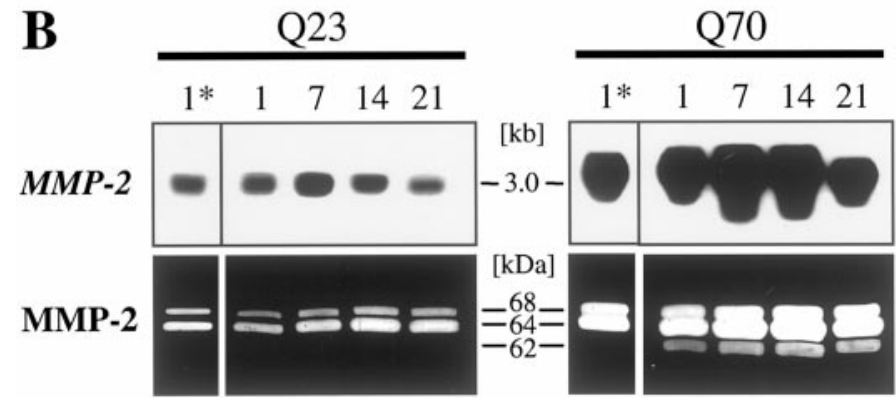

Q70

Figure 2. Time course analysis of altered $M M P-2$ gene expression in nonexpanded and expanded ataxin-3-expressing SCA3 cell lines. SCAQ23 and SCA3-Q70 cells were cultured at $33^{\circ} \mathrm{C}(A)$ and $39^{\circ} \mathrm{C}(B)$ in either tetracycline-free medium for $1,7,14$, and $21 \mathrm{~d}$ to induce or in tetracyclinecontaining medium for $1 \mathrm{~d}\left(1^{*}\right)$ to suppress expression of the recombinant ataxin-3 isoforms. At the indicated times, total RNA and concentrated medium were prepared simultaneously from cultured cells and analyzed by Northern blot and gelatin zymography, respectively. Northern blot analysis (top panels) was performed using $10 \mu \mathrm{g}$ of RNA of each sample and the $M M P$-2-specific cDNA probe detecting $M M P-2$ mRNA as a single $3.0 \mathrm{~kb}$ band. Equal loading of RNA in each lane was verified by methylene blue staining of $28 \mathrm{~S}$ and $18 \mathrm{~S}$ RNA species (data not shown). Gelatin zymography (bottom panels) was performed using $50 \mu \mathrm{g}$ of protein of concentrated medium from each condition. Cleared proteolytic zones indicated the presence of gelatinases at their respective molecular weights and were assigned to the latent form of pro MMP-2 with $68 \mathrm{kDa}$, the intermediate and fully activated form of MMP-2 with 64 and $62 \mathrm{kDa}$, respectively.

diate forms (68 and $64 \mathrm{kDa}$ ) of MMP-2 were apparent in SCAQ23 cells, the fully activated form of MMP-2 $(62 \mathrm{kDa})$ was not detectable at any time point (Fig. $2 B$ ). Together, the increased $M M P-2$ mRNA levels in SCA3-Q70 cells correlated with an increased expression of secreted functionally active MMP-2 forms.

The rat $M M P$-2 gene is homologous to the human $M M P$-2 gene, formerly known as type IV collagenase gene (Huhtala et al., 1990). To verify altered expression of MMP-2 in human disease tissue, we examined pons sections of two SCA3 patients and three controls by immunohistochemistry. Whereas only few weakly MMP-2-immunoreactive neurons were present in healthy human pons (Fig. $3 A$ ), examination of SCA3 brains revealed MMP-2immunoreactive pontine neurons with a strong cytoplasmic staining (Fig. 3B). Coimmunofluorescence staining with anti-ubiquitin and anti-MMP-2 identified NIs in most of the MMP-2-positive pontine neurons (Fig. 3C-E).

\section{Upregulation of $A P P$ and enhanced expression of $A \beta$ peptides in SCA3 pons}

Clone 2 corresponded to 225 bp of the coding region of the rat APP (Shivers et al., 1988). Rat APP displays 97\% identity to human APP (Ponte et al., 1988), an integral membrane protein that is ubiquitously and abundantly expressed in neurons (Kang et al., 1987). Northern analysis revealed a significant upregulation of two major transcripts $(\sim 2.8$ and $\sim 3.4 \mathrm{~kb})$ in SCA3-Q70 clonal cell lines at $33^{\circ} \mathrm{C}$ compared with SCA3-Q23 clonal cell lines and the control cell line (Fig. $1 \mathrm{~A}$ ). At $39^{\circ} \mathrm{C}$, a significant upregulation of $A P P$ mRNA was only present in SCA3-Q70 clonal cell line 1 , which corresponded to an increased amount of expanded $S C A 3$ mRNA and ataxin-3 protein (Fig. $1 B$ ).

Because cleavage of APP can generate cytotoxic A $\beta$ peptides resulting in formation of $\mathrm{A} \beta$-positive deposits in Alzheimer's disease (Yankner et al., 1989), we performed immunostaining of SCA3 and control pons sections with a polyclonal antibody against $\mathrm{A} \beta$. Large densely $\mathrm{A} \beta$-immunoreactive deposits were detected in SCA 3 pons sections $(n=9 \pm 2$ and $n=10 \pm 2$ per section) (Fig. $3 G$ ) but were less frequent in control pons sections ( $n=0.5 \pm 0.5, n=0.5 \pm 0.5$, and $n=4 \pm 1.5$ per section) (Fig. $3 F)$. The form and morphology of these $\mathrm{A} \beta$-immunoreactive deposits closely resembled degenerated neurons. Some pontine neurons also exhibited a distinct cytoplasmic staining of $\mathrm{A} \beta(n=$ $5 \pm 1$ and $n=10 \pm 1$ per section) (Fig. $3 H$ ), suggesting an intracellular accumulation of $\mathrm{A} \beta$. In contrast, only few pontine neurons with a faint intracellular $\mathrm{A} \beta$-immunostaining were observed in controls $(n=0.5 \pm 0.5, n=2 \pm 1$, and $n=3 \pm 3$ per section). Coimmunofluorescence staining with anti-ubiquitin showed that $\mathrm{A} \beta$-positive neurons also contained NIs (Fig. 3I-K).

\section{Upregulation of Fit-1S corresponds to increased IL-1ra and IL-1 $\beta$ staining in SCA3 pons}

Clone 3 represented 165 bp of the $3^{\prime}$ noncoding region of the rat Fit-1 gene encoding Fit-1S (Bergers et al., 1994). Fit-1 gene expression generates two different mRNA isoforms coding for the secreted (Fit-1S) and membrane-bound (Fit-1M) proteins, which are closely related to the extracellular domain or the entire protein of rat IL-1 receptor, respectively (Hart et al., 1993). The Fit-1S mRNA was detected as a single transcript of $\sim 2.6 \mathrm{~kb}$ in all clonal cell lines. In SCA3-Q70 clonal cell line 2, Fit-1S mRNA expression was significantly increased at both temperatures (Fig. $1 A$ ). In contrast, we found an increase of Fit-1S transcript in SCA3-Q70 clonal cell line 1 only at $33^{\circ} \mathrm{C}$ (Fig. $1 A$ ). The differences between both SCA3-Q70 clonal cell lines in altered Fit -1S mRNA gene expression at $39^{\circ} \mathrm{C}$ did not correspond to the amount of expanded SCA3 mRNA and ataxin-3 protein (Fig. $1 B$ ).

Fit-1S binds the proinflammatory cytokine IL-1 $\beta$ and is believed to have a function comparable with that of the IL-1ra (Reikerstorfer et al., 1995). Immunohistochemical analyses using a polyclonal antibody directed against human IL-1ra revealed a strong cytoplasmic staining of pontine neurons in both SCA3 patients (Fig. $4 B$ ), whereas control pons sections did not show IL-1ra-positive neurons (Fig. 4A). Furthermore, increased numbers of IL-1ra-positive plaque-like structures, often associated with IL-1ra-positive neurons (Fig. 4C), were apparent in SCA3 cases, whereas similar structures were less frequently found in controls. In addition, increased numbers of IL- $1 \beta$-positive pontine neurons showing an enhanced cytoplasmic immunostaining were detected in both SCA3 patients (Fig. 4E) compared with control subjects (Fig. 4D).

\section{Upregulation of SDF1 $\alpha$ and $S D F 1 \beta$ and enhanced expression of SDF1 in SCA3 pons}

Clones 4 and 5 matched the $3^{\prime}$ noncoding region of the rat SDF1 $\alpha$ and SDF1 $\beta$, respectively (Nagasawa et al., 1994; Nomura et al., 1996). The small cytokines SDF1 $\alpha$ and SDF1 $\beta$ belong to the intercrine family of chemoattractants, which are involved in cell migration during inflammation (Bajetto et al., 1999). Whereas 

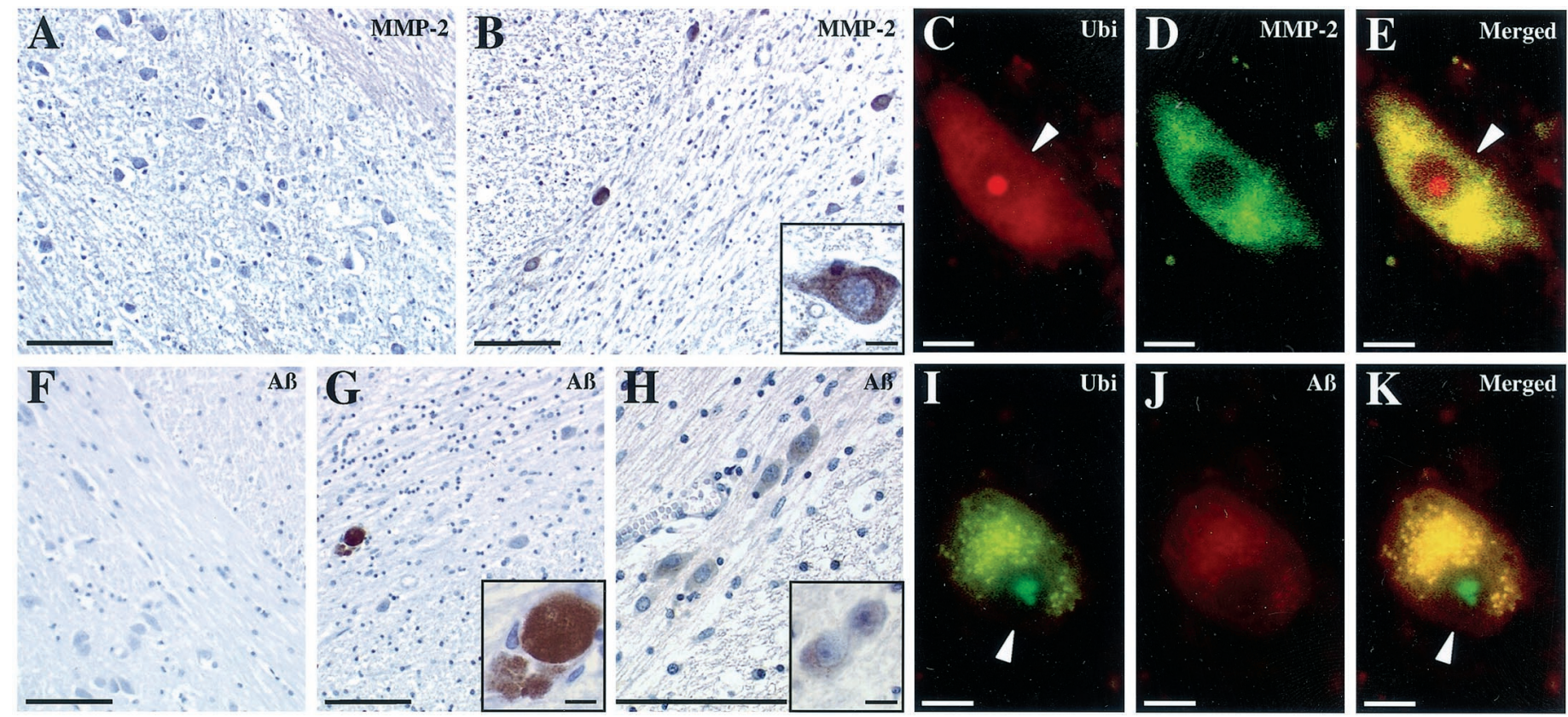

Figure 3. Increased cytoplasmic expression of MMP-2 and $\mathrm{A} \beta$ in pontine neurons containing ubiquitinated intranuclear inclusions in SCA3 pons. MMP-2 immunohistochemical staining of control pons $(A)$ compared with diseased pons $(B)$ showed several pontine neurons with strong cytoplasmic immunoreactivity ( $B$ and inset). Coimmunofluorescence staining of SCA3 pons sections using anti-ubiquitin $(C$, red $)$ and anti-MMP-2 $(D$, green) demonstrated that a ubiqitinated NI (red) is present within the nucleus of the same MMP-2-positive neuron as confirmed by merging the images $(E$, yellow). A $\beta$ immunohistochemical staining of control pons $(F)$ compared with diseased pons $(G, H)$ showed a large densely immunoreactive deposit $(G$ and inset) and several pontine neurons with a distinct cytoplasmic staining ( $H$ and inset). Coimmunofluorescence staining of SCA3 pons sections using anti-ubiquitin $(I$, green $)$ and anti-A $\beta(J$, red $)$ demonstrated that ubiqitinated NIs ( green) are present within the nucleus of the same A $\beta$-positive neuron as confirmed by merging the images (K, yellow). Tissue sections presented in $A, B, F, G$, and $H$ were counterstained with hematoxylin. White arrowheads indicate the position of ubiquitinated NIs. Scale bars: $A, B, F-H, 100 \mu \mathrm{m} ; C-E, I-K$, insets, $10 \mu \mathrm{m}$.

Northern analysis using the isolated cDNAs as specific probes showed a significant increase of SDF1 $\alpha$ mRNA $(\sim 2.0 \mathrm{~kb})$ in SCA3-Q70 clonal cell lines at both temperatures (Fig. 1A), the increase of $S D F 1 \beta$ mRNA $(\sim 2.4 \mathrm{~kb})$ was only modest and restricted to one clonal cell line (data not shown). The differences between SCA3-Q70 clonal cell lines 1 and 2 in the SDF1 $\alpha$ mRNA amount at $39^{\circ} \mathrm{C}$ corresponded to the relative amounts of expanded $S C A 3$ mRNA and ataxin-3 protein (Fig. $1 B$ ).

SDF1 $\alpha$ and SDF1 $\beta$ sequences differ only by the presence of additional four amino acids at the C terminus of SDF1 $\beta$ and are $>92 \%$ identical to those of the human counterparts (Shirozu et al., 1995). Immunohistochemistry of SCA3 pons sections using a polyclonal antibody directed against both human homologous isoforms of SDF1 revealed a stronger cytoplasmic staining of pontine neurons (Fig. $4 G$ ) in SCA3 compared with controls (Fig. 4F).

\section{Increased numbers of activated microglial cells and reactive astrocytes in SCA3 pons}

To further study inflammatory involvement in SCA3, we performed immunostaining for microglia and astrocytes. Analyses of the microglial marker CD68 revealed an increased number of activated perineuronal microglial cells in both SCA3 patients (Fig. 4I) compared with controls (Fig. 4H). Furthermore, we also found a significant increase of strongly IL- $1 \beta$-positive astrocytes (Fig. $4 K$ ) in disease tissue, whereas control sections of the respective pons region only showed few IL- $1 \beta$-immunoreactive astrocytes (Fig. 4J). Immunostaining against the astrocytic marker GFAP confirmed the presence of increased numbers of reactive astrocytes in both SCA3 patients (data not shown).

\section{DISCUSSION}

In the present study, we found increased expression of mRNAs encoding MMP-2, APP, Fit-1S, and SDF1 $\alpha$ in rat CSM14.1 cell lines stably expressing expanded human full-length ataxin-3. In CSM14.1 cells, upregulation of these genes was found in independently isolated SCA3-Q70 clonal cell lines $7 \mathrm{~d}$ after induced expression of expanded ataxin-3, a time point when NIs are already present but $14 \mathrm{~d}$ before the occurrence of neuronal cell death (Evert et al., 1999). In addition, increased expression of the respective (MMP-2 and SDF1) or associated (A $\beta$, IL-1ra, and $\mathrm{IL}-1 \beta$ ) proteins was demonstrated in human SCA3 pontine neurons.

Interestingly, the identified molecules either represent inflammatory mediators (IL-1ra, IL-1 $\beta$, and SDF1) or membraneassociated constituents (MMP-2 and $\mathrm{A} \beta$ ) that are known to be involved in other CNS diseases. Elevated levels of MMP-2 and MMP-9 were identified in Alzheimer's disease hippocampal tissue and white matter (Backstrom et al., 1992; Yamada et al., 1995) and were also found to be increased in CSF of subjects with a variety of inflammatory neurological disorders (Gijbels et al., 1992). Time course analysis revealed that neuronally differentiated SCA3-Q70 cells have an additional increase of both $M M P-2$ mRNA and MMP-2 protein at $39^{\circ} \mathrm{C}$ with a maximum at $14 \mathrm{~d}$, whereas $M M P-2$ gene expression remained more or less constant in SCA3-Q23 cells. Although the reason for the altered MMP-2 gene expression in SCA3-Q70 cells is unknown, these results suggest that neuronally differentiated cells expressing expanded ataxin-3 are unable to suppress the upregulation of the MMP-2 gene expression. Whether the $M M P-2$ upregulation coincides 

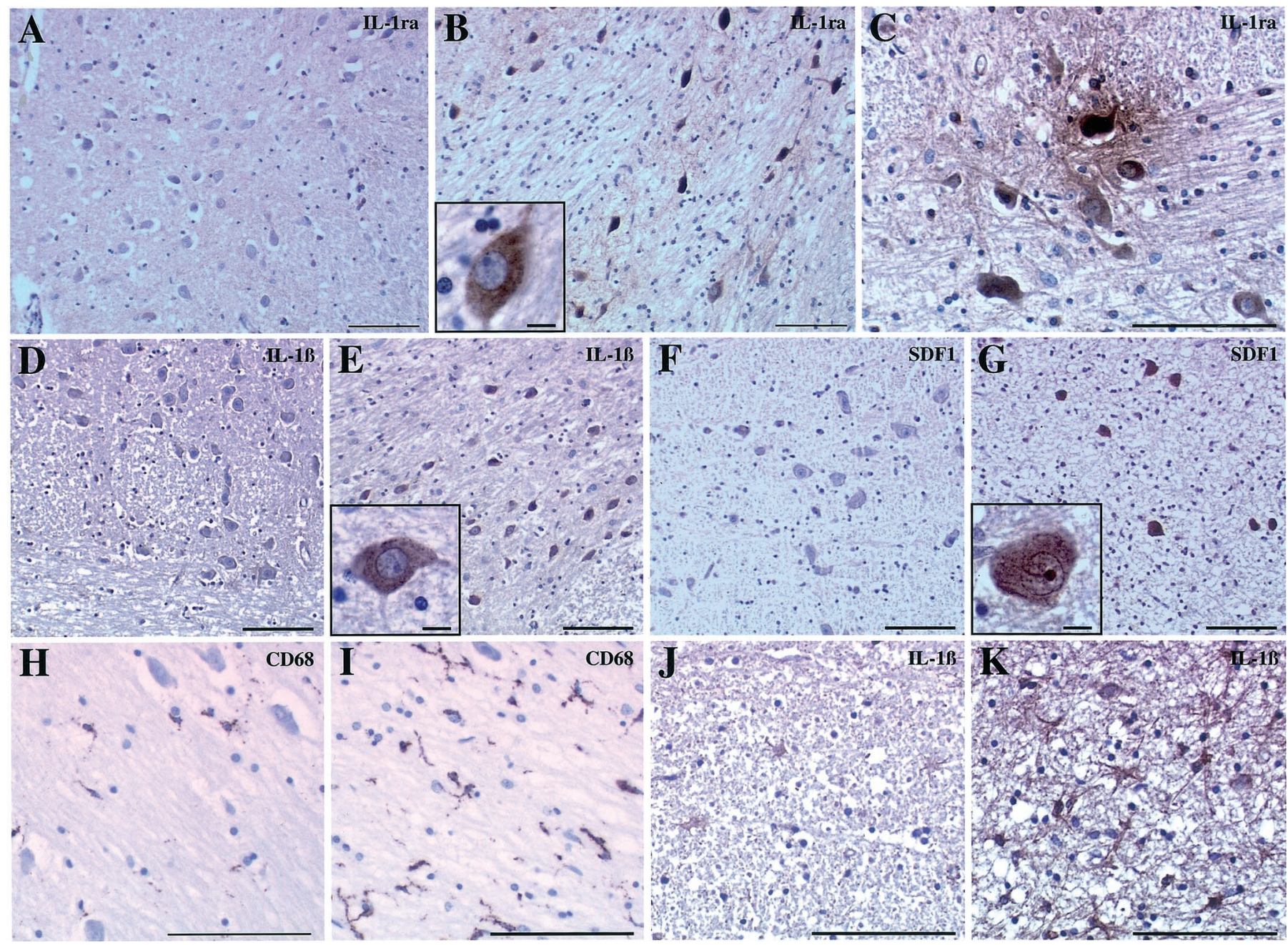

Figure 4. Altered expression of the inflammatory mediators IL-1ra, IL-1 $\beta$, and SDF1 and increased numbers of CD68- and IL-1 $\beta$-immunoreactive glial cells in pons sections of diseased SCA3 brain. Comparison of IL-1ra-immunostained control $(A)$ and disease pons sections $(B, C)$ revealed a significantly increased cytoplasmic staining of pontine neurons $(B$ and inset) and several immunoreactive plaque-like structures $(C)$ in SCA3 patients. Comparison of IL-1 $\beta$-immunostained control $(D)$ and disease pons sections $(E)$ showed an enhanced staining of pontine neurons $(E$ and inset) in SCA3 patients. Immunohistochemical analysis using anti-SDF1 antibodies showed an intense staining of pontine neurons in SCA3 cases $(G)$ that was also present in controls but to a much lesser extent $(F)$. Immunostaining for CD68 revealed several positive perineuronal cells displaying a typical morphology of activated microglia in SCA3 pons $(I)$, whereas CD68-positive cells were less frequently in controls $(H)$. Immunohistochemical analysis against IL-1 $\beta$ showed a significant increase of reactive astrocytes in SCA3 pons $(K)$ compared with control pons section $(J)$. Tissue sections were counterstained with hematoxylin. Scale bars: $A-K, 100 \mu \mathrm{m}$; insets, $10 \mu \mathrm{m}$.

with or contributes to the spontaneous neuronal cell death after $14 \mathrm{~d}$ expression of induced expanded ataxin-3 (Evert et al., 1999) remains to be determined. However, the significant increase of $M M P-2$ mRNA and MMP-2 protein in SCA3-Q70 clonal cell lines was further corroborated by an increased cytoplasmic staining of MMP-2 in affected pontine neurons of SCA3 patients, suggesting an involvement of MMP-2 in SCA3 pathogenesis. However, the upregulation of MMP-2 in SCA3 or in other CNS pathologies might not always be harmful, and thus it is important for future studies to discriminate between the beneficial and deleterious effects of MMPs.

In addition to a significant increase of MMP-2 in cells expressing expanded ataxin-3 and increased cytoplasmic staining of MMP-2 in NI-containing pontine neurons of SCA3 patients, we found a distinct upregulation of $A P P$ in SCA3-Q70 clonal cell lines. This result was extended by the demonstration of $\mathrm{A} \beta$ positive deposits and several $\mathrm{A} \beta$-positive pontine neurons in human SCA3 pons. The enhanced intracellular staining of $\mathrm{A} \beta$ in neurons of SCA3 pons is suggestive for an altered proteolytic processing of APP probably associated with an A $\beta$-induced cellular stress.

MMP-2 and APP may interact in a complex way. MMP-2 has been reported to cleave A $\beta$ (Miyazaki et al., 1993, 1994), as well as the full-length APP (Roher et al., 1994), suggesting that MMP-2 prevents $\mathrm{A} \beta$ accumulation. In contrast, MMP- 2 has been shown to have $\beta$-secretase activity and therefore would generate A $\beta$ peptides (LePage et al., 1995). Thus, increased MMP-2 expression in SCA3 tissue may reflect either a pathogenic change or a compensatory reaction to counteract $\mathrm{A} \beta$ toxicity. In support of a protective role of MMPs in $\mathrm{A} \beta$-mediated cytotoxicity, several reports demonstrated a significant increase of MMP-2, MMP-3, and MMP-9 in glial and neuronal cells during exposure to A $\beta$ peptides (Backstrom et al., 1996; Deb and Gottschall, 1996; Deb et al., 1999).

Despite the controversial role of MMPs in generation or degradation of $\mathrm{A} \beta$ peptides, it is well known that the expression of 
MMPs is regulated by growth factors, cytokines, and steroids. In cultured astrocytes, IL-1, tumor necrosis factor- $\alpha$ (TNF- $\alpha$ ), and lipopolysaccharide (LPS) are potent stimulators of MMP-2 and MMP-9 expression (Gottschall and Yu, 1995). Interestingly, the increased expression of the Fos-responsive Fit-1S gene in neuronal cell lines expressing expanded ataxin-3 suggests that molecules related to the IL-1 family play a role in SCA3. Although a direct ortholog for Fit-1S has not been identified, the secreted Fit-1S protein closely resembles the extracellular domain of rat type I IL-1-receptor (Hart et al., 1993) and specifically binds IL-1 $\beta$ (Reikerstorfer et al., 1995). The physiological function of Fit-1S is believed to be similar to IL-1ra, which functions as a selective competitive receptor antagonist and blocks all known actions of the proinflammatory cytokine IL-1 (Bergers et al., 1994; Rothwell et al., 1997). The intracellular isoforms of IL-1ra are proposed to represent a reservoir that is released during cell death to limit the proinflammatory action (Muzio et al., 1999). The finding that pontine neurons of SCA3 patients showed a significantly increased expression of IL-1ra, as well as IL-1rapositive plaque-like structures, may thus reflect a compensatory reaction in response to the inflammatory action of IL-1 $\beta$. In agreement with the upregulation of IL-1ra, we also found enhanced IL- $1 \beta$ staining of pontine neurons in SCA3 tissue. Thus, two functionally related inflammatory mediators were present in disease tissue, supporting the involvement of an inflammatory process in SCA3. In support of this, we found increased numbers of activated microglial cells, as well as reactive astrocytes, in both SCA3 pons sections, suggesting a possible role for microglial activation in SCA3. Microglial cells are the resident macrophages of the CNS and thus form the interface between the neural parenchyme and the immune system (Kreutzberg, 1996).

Aberrant synthesis of IL- $1 \beta$ in the brain contributes to the development of acute and chronic CNS pathologies such as Alzheimer's disease, Down's syndrome, and multiple sclerosis (Griffin et al., 1989; Rothwell et al., 1997; Huitinga et al., 2000). Interestingly, increased expression of IL- $1 \beta$ and MMPs occurs simultaneously at sites of inflammation in which MMPs have been shown to control the biological activity of IL-1 $\beta$ (Ito et al., 1996; Schönbeck et al., 1998). Therefore, it is conceivable that the observed increased MMP-2 expression in SCA3-Q70 cells and SCA3 brains results in enhanced formation of active IL- $1 \beta$.

The increased expression of SDF1 $\alpha$ mRNA in SCA3-Q70 cell lines expressing expanded ataxin-3 provides additional evidence for a polyglutamine-induced inflammatory response. The cytokine SDF1 $\alpha$ belongs to the intercrine CXC (Cys-Xxx-Cys) subfamily of chemoattractants that are involved in activation of neutrophil leukocytes. SDF1 and its physiological receptor CXCR4 are expressed by astrocytes, cortical neurons, and cerebellar granule cells (Ma et al., 1998). Interestingly, these cytokines are induced by proinflammatory stimuli, such as IL-1, TNF- $\alpha$, and LPS (Ohtani et al., 1998).

The identification of several upregulated inflammatory mediators in ataxin-3-expressing cell lines and disease brains may reflect a mechanism responsible for the loss of neurons in SCA3 pathogenesis. It is important to note that the altered gene expression was identified in neuronal cell lines that are not contaminated by glial cells. Moreover, the corresponding changes observed in human SCA3 pons were observed in affected pontine neurons and the extracellular matrix but not in glial cells. For these reasons, the observed changes are not attributable to an unspecific glial activation. At present, it is not possible to decide whether the upregulation of proteins involved in inflammation is an essential step in the pathogenesis of SCA3 or whether it is a compensatory response aimed at maintaining cellular function and integrity. It is unlikely that the reported changes represent an early event in the pathophysiology of SCA3 because upregulation was observed at a time point when NIs were already present. In addition, the changes observed in vitro were also present in human postmortem tissue, i.e., in a late or end stage of the disease. Interestingly, the only gene found to be upregulated in transgenic SCA1 mice encodes $\alpha_{1}$-antichymotrypsin, a protein involved in inflammation (Lin et al., 2000). In the temporal sequence of altered gene expression, upregulation of $\alpha_{1}$-antichymotrypsin represents a late event after downregulation of a number of genes not related to inflammation.

In future studies, it will be important to characterize the temporal expression pattern of the proteins that we found to be upregulated in SCA3. In addition, studies using pharmacological or genetic approaches to inhibit the activity of these proteins are needed to clarify the pathogenetic role of the respective proteins. If these studies provide evidence for cell-damaging actions of the proteins identified in this study, antiinflammatory drugs may be envisioned for future treatment of SCA3.

\section{REFERENCES}

Backstrom JR, Miller CA, Tokes ZA (1992) Characterization of neural proteinases from Alzheimer-affected and control brain specimen: identification of calcium-dependent metalloproteinases from the hippocampus. J Neurochem 58:983-992.

Backstrom JR, Lim GP, Cullen MJ, Tokes ZA (1996) Matrix metalloproteinase-9 (MMP-9) is synthesized in neurons of the human hippocampus and is capable of degrading the amyloid- $\beta$ peptide. J Neurosci 16:7910-7919.

Bajetto A, Bonavia R, Barbero S, Piccioli P, Costa A, Florio T, Schettini G (1999) Glial and neuronal cells express functional chemokine receptor CXCR4 and its natural ligand stromal cell-derived factor 1. J Neurochem 73:2348-2357.

Bergers G, Reikerstorfer A, Braselmann S, Graninger P, Busslinger M (1994) Alternative promoter usage of the fos-responsive gene Fit-1 generates mRNA isoforms coding for either secreted or membranebound proteins related to the IL-1 receptor. EMBO J 13:1176-1188.

Bürk K, Abele M, Fetter M, Dichgans J, Skalej M, Laccone F, Didierjean O, Brice A, Klockgether T (1996) Autosomal dominant cerebellar ataxia type I clinical features and MRI in families with SCA1, SCA2 and SCA3. Brain 119:1497-1505.

Chai Y, Koppenhafer SL, Shoesmith SJ, Perez MK, Paulson HL (1999a) Evidence for proteasome involvement in polyglutamine disease: localization to nuclear inclusions in SCA3/MJD and suppression of polyglutamine aggregation in vitro. Hum Mol Genet 8:673-682.

Chai Y, Koppenhafer SL, Bonini NM, Paulson HL (1999b) Analysis of the role of heat shock protein (Hsp) molecular chaperones in polyglutamine diseases. J Neurosci 19:10338-10347.

Cummings JC, Zoghbi HY (2000) Fourteen and counting: unraveling trinucleotide repeat diseases. Hum Mol Genet 9:909-916.

Deb S, Gottschall PE (1996) Increased production of matrix metalloproteinases in enriched astrocyte and mixed hippocampal cultures treated with $\beta$-amyloid peptides. J Neurochem 66:1614-1647.

Deb S, Zhang W, Gottschall PE (1999) Activated isoforms of MMP-2 are induced in U87 human glioma cells in response to $\beta$-amyloid peptide. J Neurosci Res 55:44-53.

Dürr A, Stevanin G, Cancel G, Duyckaerts C, Abbas N, Didierjean O, Chneiweiss H, Benomar A, Lyon-Caen O, Julien J, Serdaru M, Penet C, Agid Y, Brice A (1996) Spinocerebellar ataxia 3 and MachadoJoseph disease: clinical, molecular, and neuropathological features. Ann Neurol 39:490-499.

Evert BO, Wüllner U, Schulz JB, Weller M, Groscurth P, Trottier Y, Brice A, Klockgether T (1999) High level expression of expanded full-length ataxin-3 in vitro causes cell death and formation of intranuclear inclusions in neuronal cells. Hum Mol Genet 8:1169-1176.

Evert BO, Wüllner U, Klockgether T (2000) Cell death in polyglutamine diseases. Cell Tissue Res 301:189-204.

Gijbels K, Masure S, Carton H, Opdenakker G (1992) Gelatinase in the cerebrospinal fluid of patients with multiple sclerosis and other inflammatory neurological disorders. J Neuroimmunol 41:29-34.

Gottschall PE, Yu X (1995) Cytokines regulate gelatinase A and B (matrix metalloproteinase; MMP-2 and MMP-9) activity in cultured rat astrocytes. J Neurochem 64:1513-1520.

Griffin WS, Stanley LC, Ling C, White L, MacLeod V, Perrot LJ, White 
CL 3d, Araoz C (1989) Brain interleukin 1 and S-100 immunoreactivity are elevated in Down syndrome and Alzheimer disease. Proc Natl Acad Sci USA 86:7611-7615.

Harendza S, Pollock AS, Mertens PR, Lovett DH (1995) Tissue-specific enhancer-promoter interactions regulate high level constitutive expression of matrix metalloproteinase 2 by glomerular mesangial cells. J Biol Chem 270:18786-18796.

Hart RP, Liu C, Shadiack AM, McCormack RJ, Jonakait GM (1993) An mRNA homologous to interleukin-1 receptor type I is expressed in cultured rat sympathetic ganglia. J Neuroimmunol 44:49-56.

Huhtala P, Chow LT, Tryggvason K (1990) Structure of the human type IV collagenase gene. J Biol Chem 265:11077-11082.

Huitinga I, van der Cammen M, Salm L, Erkut Z, van Dam AM, Tilders F, Swaab D (2000) IL-1 $\beta$ immunoreactive neurons in the human hypothalamus: reduced numbers in multiple sclerosis. J Neuroimmunol 107:8-20.

Ito A, Mukaiyama A, Itoh Y, Nagase H, Thogersen IB, Enghild JJ, Sasaguri Y, Mori Y (1996) Degradation of interleukin $1 \beta$ by matrix metalloproteinases. J Biol Chem 271:14657-14660.

Kang J, Lemaire H-G, Unterbeck A, Salbaum JM, Masters CL, Grzeschik KH, Multhaup G, Beyreuther K, Müller-Hill B (1987) The precursor of Alzheimer's disease amyloid A4 protein resembles a cell-surface receptor. Nature 325:733-736.

Kaytor MD, Duvick LA, Skinner PJ, Koob MD, Ranum LPW, Orr HT (1999) Nuclear localization of the spinocerebellar ataxia type 7 protein, ataxin-7. Hum Mol Genet 8:1657-1664.

Klement IA, Skinner PJ, Kaytor MD, Yi H, Hersch SM, Clark HB, Zoghbi HY, Orr HT (1998) Ataxin-1 localization and aggregation: role in polyglutamine-induced disease in SCA1 transgenic mice. Cell 95:41-53.

Kreutzberg GW (1996) Microglia: a sensor for pathological events in the CNS. Trends Neurosci 19:312-318.

LePage RN, Fosang AJ, Fuller SJ, Murphy G, Evin G, Beyreuther K, Masters CL, Small DH (1995) Gelatinase A possesses a $\beta$-secretaselike activity in cleaving the amyloid protein precursor of Alzheimer's disease. FEBS Letters 377:267-270.

Lin X, Antalffy B, Kang D, Orr HT, Zoghbi HY (2000) Polyglutamine expansion downregulates specific neuronal genes before pathologic changes in SCA1. Nat Neurosci 3:157-163.

Luthi-Carter R, Strand A, Peters NL, Solano SM, Hollingsworth ZR, Menon AS, Frey AS, Spektor BS, Penney EB, Schilling G, Ross CA, Borchelt DR, Tapscott SJ, Young AB, Cha JHC, Olson JM (2000) Decreased expression of striatal signaling genes in a mouse model of Huntington's disease. Hum Mol Genet 9:1259-1271.

Ma Q, Jones D, Borghesani PR, Segal RA, Nagasawa T, Kishimoto T, Bronson R, Springer TA (1998) Impaired B-lymphopoiesis, myelopoiesis, and derailed cerebellar neuron migration in CXCR4- and SDF-1 deficient mice. Proc Natl Acad Sci USA 95:9448-9453.

McCampbell A, Taylor JP, Taye AA, Robitschek J, Li M, Walcott J, Merry D, Chai Y, Paulson H, Sobue G, Fischbeck KH (2000) CREBbinding protein sequestration by expanded polyglutamine. Hum Mol Genet 9:2197-2202.

Miyazaki K, Hasegawa M, Funahashi K, Umeda M (1993) A metalloproteinase inhibitor domain in Alzheimer amyloid protein precursor. Nature 362:839-841.

Miyazaki K, Funahashi K, Umeda M, Nakano A (1994) Gelatinase A and APP. Nature 368:695-696.

Muzio M, Polentarutti N, Facchetti F, Peri G, Doni A, Sironi M, Transidico P, Salmona M, Introna M, Mantovani A (1999) Characterization of type II intracellular IL-1 receptor antagonist (IL-1ra3): a depot IL-1ra. Eur J Immunol 29:781-788.

Nagasawa T, Kikutani H, Kishimoto T (1994) Molecular cloning and structure of a pre-B-cell growth-stimulating factor. Proc Natl Acad Sci USA 91:2305-2309.

Nomura M, Matsuda Y, Itoh H, Hori T, Suzuki G (1996) Genetic mapping of the mouse stromal cell-derived factor gene (Sdf1) to mouse and rat chromosomes. Cytogenet Cell Genet 73:286-289.

Ohtani Y, Minami M, Kawaguchi N, Nishiyori A, Yamamoto J, Takami S, Satoh M (1998) Expression of stromal cell-derived factor-1 and CXCR4 chemokine receptor mRNAs in cultured rat glial and neuronal cells. Neurosci Lett 249:163-166.

Paulson HL (2000) Toward an understanding of polyglutamine neurodegeneration. Brain Pathol 10:293-299.

Paulson HL, Das SS, Crino PB, Perez MK, Patel SC, Gotsdiner D, Fischbeck KH, Pittman RN (1997a) Machado-Joseph disease gene product is a cytoplasmic protein widely expressed in brain. Ann Neurol 41:453-462.
Paulson HL, Perez MK, Trottier Y, Trojanowski JQ, Subramony SH, Das SS, Vig P, Mandel JL, Fischbeck KH, Pittman RN (1997b) Intranuclear inclusions of expanded polyglutamine protein in spinocerebellar ataxia type 3. Neuron 19:333-344.

Perez MK, Paulson HL, Pendse SJ, Saionz SJ, Bonini NM, Pittman RN (1998) Recruitment and the role of nuclear localization in polyglutamine-mediated aggregation. J Cell Biol 143:1457-1470.

Perez MK, Paulson HL, Pittman RN (1999) Ataxin-3 with an altered conformation that exposes the polyglutamine domain is associated with the nuclear matrix. Hum Mol Genet 8:2377-2385.

Ponte P, Gonzalez-deWhitt P, Schilling J, Miller J, Hsu D, Greenberg B, Davis K, Wallace W, Lieberburg I, Fuller F, Cordell B (1988) A new A4 amyloid mRNA contains a domain homologous to serine proteinase inhibitors. Nature 331:525-527.

Reikerstorfer A, Holz H, Stunnenberg HG, Busslinger M (1995) Low affinity of interleukin- $1 \beta$ and intracellular signaling via $\mathrm{NF}-\kappa \mathrm{B}$ identify Fit-1 as a distant member of the interleukin-1 receptor family. J Biol Chem 270:17645-17648

Robitaille Y, Loppes-Cendes I, Becher M, Rouleau GA, Clark AW (1997) The neuropathology of CAG repeat diseases: review and update of genetic and molecular features. Brain Pathol 7:901-926.

Roher AE, Kasunic TC, Woods AS, Cotter RJ, Ball MJ, Fridman R (1994) Proteolysis of A beta peptide from Alzheimer disease brain by gelatinase A. Biochem Biophys Res Commun 205:1755-1761.

Rothwell N, Allan S, Toulmond S (1997) The role of interleukin 1 in acute neurodegeneration and stroke: pathophysiological and therapeutic implications. J Clin Invest 100:2648-2652

Saudou F, Finkbeiner S, Devys D, Greenberg ME (1998) Huntingtin acts in the nucleus to induce apoptosis but death does not correlate with the formation of intranuclear inclusions. Cell 95:55-66.

Schmidt T, Landwehrmeyer GB, Schmitt I, Trottier Y, Auburger G, Laccone F, Klockgether T, Völpel M, Epplen JT, Schöls L, Riess O (1998) An isoform of ataxin-3 accumulates in the nucleus of neuronal cells in affected brain regions of SCA3 patients. Brain Pathol 8:669-679.

Schönbeck U, Mach F, Libby P (1998) Generation of biologically active IL- $1 \beta$ by matrix metalloproteinases: a novel caspase-1-independent pathway of IL-1 $\beta$ processing. J Immunol 161:3340-3346.

Shirozu M, Nakano T, Inazawa J, Tashiro K, Tada H, Shinohara T, Honjo T (1995) Structure and chromosomal localization of the human stromal-cell derived factor 1 (SDF1) gene. Genomics 28:495-500.

Shivers BD, Hilbich C, Multhaup G, Salbaum M, Beyreuther K, Seeburg PH (1988) Alzheimer's disease amyloidgenic glycoprotein: expression pattern in rat brain suggests a role in cell contact. EMBO J 7:1365-1370.

Skinner PJ, Koshy BT, Cummings CJ, Klement IA, Helin K, Servadio A, Zoghbi HY, Orr HT (1997) Ataxin-1 with an expanded glutamine tract alters nuclear matrix-associated structures. Nature 389:971-974.

Tait D, Riccio M, Sittler A, Scherzinger E, Santi S, Ognibene A, Maraldi NM, Lehrach H, Wanker EE (1998) Ataxin-3 is transported into the nucleus and associates with the nuclear matrix. Hum Mol Genet 7:991-997.

Takiyama Y, Oyanagi S, Kawashima S, Sakamoto H, Saito K, Yoshida M, Tsuji S, Mizuno Y, Nishizawa M (1994) A clinical and pathologic study of a large Japanese family with Machado-Joseph disease tightly linked to the DNA markers on chromosome 14q. Neurology 44:1302-1308.

Trottier Y, Cancel G, An-Gourfinkel I, Lutz Y, Weber C, Brice A, Hirsch E, Mandel JL (1998) Heterogenous intracellular localization and expression of ataxin-3. Neurobiol Dis 5:335-347.

Warrick JM, Chan HY, Gray-Board GL, Chai Y, Paulson HL, Bonini NM (1999) Suppression of polyglutamine-mediated neurodegeneration in Drosophila by the molecular chaperone HSP70. Nat Genet 23:425-428.

Woessner JFJ (1991) Matrix metalloproteinases and their inhibitors in connective tissue remodeling. FASEB J 5:2145-2154.

Wüllner U, Kornhuber J, Weller M, Schulz JB, Löschmann PA, Riederer $\mathrm{P}$, Klockgether T (1999) Cell death and apoptosis regulating proteins in Parkinson's disease - a cautionary note. Acta Neuropathol 97:408-412.

Yamada T, Miyazaki K, Koshikawa N, Takahashi M, Akatsu H, Yamamoto T (1995) Selective localization of gelatinase A, an enzyme degrading beta-amyloid protein, in white matter microglia and in Schwann cells. Acta Neuropathol 89:199-203.

Yankner B, Dawes LR, Fisher S, Villa-Komaroff L, Oster-Granite ML, Neve RL (1989) Neurotoxicity of a fragment of the amyloid precursor associated with Alzheimer's disease. Science 245:417-420. 